\title{
Towards Remediation of Indonesian New Fine Arts
}

\author{
Iswahyudi \\ Faculty of Language and Arts, Universitas Negeri Yogyakarta, Indonesia \\ Email: iswahyudi@uny.ac.id
}

\begin{abstract}
Modern Indonesian painting mainly developed from the situation of the Dutch East Indies and Mooi-Indie art that was dominant at that time. The independence of the Republic of Indonesia became a very important milestone in the development of modern Indonesian painting. This is inseparable from the occurrence of a high dynamics and change through various political regimes in power starting from the leadership of Sukarno, Suharto and subsequent presidents. Each of these political regimes also played an important role in the development of modern art that occurred so as to bring out its own characteristics. Until the early 1990s, talking about art was something that seemed synonymous with painting. Although works of art with a combination of mediums have been included in exhibitions since the 1970s, but works in the form of paintings are still very dominant, even in some writings on art the imaginary boundary between painting and other art is discussed explicitly, but the term "Painting" is usually interchangeable with the term "fine art". The development of art that has become increasingly hybrid has helped to shape the climate and new audience, affirming real ideas that are at odds with painting that has already been established. Being different from established art knowledge, hybrid art agents become newcomers who find a place in the struggle in the realm of Indonesian art. Western characters which are an important consideration for painters become subject to change in the fourth phase. This change is caused by a variety of things, including the emphasis on the use of traditional forms, symbolic and decorative, because as a reaction to the political situation. Since 1942-1965, Indonesians have produced more figurative art. The pioneers in this field are artists who when abroad are like in the United States, Europe, and Japan already acquainted with traditional non-Western art in the arena of modern and international circuits.
\end{abstract}

Keywords: mooi-Indie art; modern Indonesian art; realism, Sudjojono; Heri Dono

\section{Introduction}

In the field of modern Indonesian painting in the Dutch East Indies and the Republic of Indonesia today it can be divided into four stages (Spanjaard, Helena, 2018, pp. 100-102). The first phase (1900-1942) Western and Eastern forms of art were dominated by the orientalism of "Mooi-Indie" art. Orientalism is based on forming a colonial image of the world of exotic and special Eastern populations. The second phase (1942-1950) carried out a lot of propaganda by the people of Indonesia to realize Indonesian art with "Indonesian identity". The event of physical resistance to independence formed a beginning for a national or Indonesian content, but was expressed in the form of Western aesthetic idioms. During the third phase (1950-1965) various types of streams developed in modern Indonesian painting, some of which were more nationally oriented and some were more internationally oriented. As in the Yogyakarta school of art which has been mutually agreed upon and of a nationalistic nature, especially about realism and expressionism forming a pole that is contrary to the Bandung school which is more internationally oriented, abstract and semi-abstract. The styles and techniques found in modern painting both Bandung and Yogyakarta, until now still based on Western criteria that are formal. 
Western character which is an important consideration for painters is undergoing a change in the fourth phase (1965-1995). This change is caused by a variety of things, including the emphasis on the use of traditional forms, symbolic and decorative, because as a reaction to the political situation. Since 1942-1965, Indonesians have produced more figurative art. This artistic tendency was beneficial for the development revolution of the Republic of Indonesia, which was proclaimed by President Sukarno in 1945. Painting during this period was financially supported by the government. After a major political change in 1965, it was to bring President Suharto into power which resulted in the art of being oriented to the leftsocialist school, so that it was not favored or dumped. At this time an effort is being made to find other solutions to give shape to the nationalistic ideal and Indonesian cultural identity (Schefold, R., 1998, pp.79-100). Indonesian artists conduct research on local forms of traditional art and use them as a source of inspiration. The pioneers in this field are artists who when abroad are like in the United States, Europe, and Japan already acquainted with traditional non-Western art in modern and international circuits.

It is a fact that this "back to the roots" process occurs through the artists who are most influenced by "Westernization" which at first sight appear to be paradoxical. This development demologizes the Dutch colonial thinking about "tradition". The supporters of Dutch culture during the period between 1900 and 1942 adopted a cultural politics in which Indonesian painters constantly received accusations that they always inspired tradition. For example in this case, is traditional Balinese art. The Dutch thought that modern Indonesian painters should learn from Indonesian workers to prevent the decline of traditional arts. In fact modern Indonesian painters are oriented to tradition. They are mostly composed of elite groups who have Western education who want to be modern. Their goals are faced with efforts made to pursue the backwardness of society by freeing themselves from traditions which from the point of view of the Orientalists in the Netherlands are much idealized.

In recent years it has been decades since President Sukarno proclaimed the independence of the Republic of Indonesia, there are those who are eager to learn the history of Dutch colonialism in Indonesia. This talk of a turbulent past is not new at all and certainly does not appear only in the latest literature before. For example, these various opinions have been expressed ahead of Indonesia's struggle for independence in the visual arts. The foundation for Indonesian modern art was laid in the late 1930s, a development that was accompanied by growing nationalist sentiments among the Indonesian population. Artists' associations such as Persagi (Persatuan Ahli Gambar Indonesia = Indonesian Image Experts Association) were established, which included artists who wanted to oppose the rules of the Dutch colonial government. They turned against the Mooi Indie genre in painting, where the landscape and life in the Dutch colony were portrayed in a romantic way. Instead of displaying this beautiful landscape, which was especially made for the Dutch in Indonesia, these artists focused on developing their own national arts and culture (Spanjaard, Helena, 2016, p. 15). They chose to determine the living conditions of Indonesians, which they drew to emphasize their identity. In the period between 1945 and 1949, the expression of nationalist sentiment in art was at its peak. The city of Yogyakarta is the center of the independence revolution and the artists who have settled here specifically reflect the struggle for freedom in their work. The city mainly depicts the realities of war, such as refugees, guerrilla fighters, and bombings, destruction in rural villages and burning houses. Although there is no special style, these scenes are often painted in a realistic, expressive, and fast way with dark colors. 


\section{Review of Literatures}

The information which until now can be obtained in the West about modern Indonesian painting is to show special signs from a field of science that must still be included in the map. An effort made the first time by an American art historian named Claire Holt. His book is considered successful in fulfilling people's taste in art in Indonesia, because some of it discusses the history of modern art (Holt, Claire, 1967, pp. 190-263). After a number of chapters, classical art has been discussed which until now has survived in the wayang and dance traditions, and then continues with the discussion on the emergence and development of modern Indonesian art. Claire Holt stressed the national problem, namely the cultural identity that the young republic of Indonesia in the 1950s continued to strive to realize. This change in the modern or Western direction by art historians in the Netherlands is often seen as a threat to Indonesian traditional culture. Nor is it a coincidence that the pioneering works in the field of modern Indonesian art come from Americans and Australians. In the late 1950s the cultural relations between Indonesia and the Netherlands were severed, so that the United States and Australia utilized to build closer relations. During the decolonization process (after 1945), these countries showed positive attention to modern Indonesian art by providing a great deal of scholarship funding for Indonesian artists (Spanjaard, Helena, 2018, p.102).

The period between 1965 and 1995 in Indonesia, there was three generations active in the field of painting. The first generation is largely self-taught learning outcomes. Among these writers, they were Affandi, Sudjojono, Hendra, Basuki Abdullah, and Dullah, resuming their pre-war styles such as realism, impressionism and expressionism. The second generation who has received education in the art academies of Bandung and Yogyakarta develop themselves in various styles. Some Bandung painters after they lived in the United States or Europe made abstract art. In the 1980s, most of them had a tendency to add various figurative elements in Indonesia. From abstract art in Bandung, some painters have moved to deepen traditional art and the elements that can change it. In Yogyakarta the same process occurs with the difference only in the choice for traditional symbolic this is more associated with the daily environment. The influence of traditional Balinese art which is known by students when they go on their study trips, is having an important influence in Yogjakarta in the framework of "back to the roots". The third generation, who in this case received education from the graduates of the first generation of the academy, from the beginning they probably already have a scale that is much broader than the first generation and second generation. They can choose from Western or Eastern picture languages. Furthermore, their insights were broadening ed by trips abroad, by participating in various international exhibitions and manifestations. The growing media influence in Indonesia accelerates this globalization process.

How the development that occurred after that period is is a relevant question to ask, because there is not much research on colonial history in Indonesia by presenting contemporary visual art. The literature on visual arts from Indonesia pays special attention to the genre of Mooi Indie in painting. Regarding this matter, Helena Spanjaard has actually tried to explain this in his work on Artists and Their Inspiration: A Guide Through the History of Indonesian Art (1930-2015) (Spanjaard, Helena, 2016, p. 15). Although there is increasing attention in the literature for contemporary art from Indonesia and general topics such as identity, tradition and politics, and the ways in which the country's colonial past is represented in this art are often underexposed. This is explained by art historian Leonor Veiga in his dissertation in 2018, about how contemporary artists from various Southeast Asian countries use indigenous traditions and culture (Veiga, Leonor, 2018, p.10). With this he briefly refers to themes such as colonialism and activism. By critically approaching existing knowledge about 
Indonesian contemporary art and relating it to colonial history and other social themes such as ecology and politics, the results of this study can provide new insights on how contemporary Indonesian artists reflect in their work about the colonial past in their country.

\section{Research Methods}

To find out about the remediation of new Indonesian art, it is carried out using the historical method or historical research method which can be defined as a systematic collection of principles and rules which are intended to assist effectively in collecting source materials from history, in assess or examine these sources critically, and present a "syn thesis" of the results achieved.This method is qualitative in the form of literature study using written sources of library collections in the form of books, journals, and other printed sources (Garraghan,G.J. 1957: 33).

Primary and secondary data collection techniques are carried out through library research which is carried out by visiting various libraries and agencies that store written materials such as the archives of the Taman Ismail Marzuki art complex in Jakarta, the National Library of the Republic of Indonesia and in the libraries of various Art Academies (student theses), in newspaper articles, in catalogs of various exhibitions, in monographs about artists and in articles produced at congresses. In general, publications that are carried out are sponsored by private parties such as collectors, gallery owners and there are trends by the artists themselves. In addition, there are various publications published by academies, the Ministry of Culture or the City government. After the search for written materials has been completed, the next step is to select and verify the data and compile it into a writing (Iswahyudi, 2020, p.469).

\section{Discussion}

\subsection{Developments during the Reign of President Sukarno and President Suharto}

After the Japanese capitulation in 1945, Sukarno proclaimed independence, although this was not yet recognized by the Dutch. Because it was not recognized, the nationalists gathered in Yogyakarta. In addition to nationalist leaders, nationalist-oriented artists also came to this city. The artists continue to make posters in the name of the revolution and organize the studios, when they meet certain issues can be discussed with other nationalists. After independence, Sukarno maintained his relationship with these artists and also collected his own art (Knol, Meta, Remco Raben and Kitty Zijlmans, 2009, p.99). Sukarno's collection consists of more than 2000 works of art. Most of the collection consists of works by nationalist artists who collaborate with him, but what is surprising is that some of the artwork collected from Indonesian artists is also based on European art. Sukarno himself liked the works of Basuki Abdullah. This artist makes naturalistic and romantic scenes and portraits, comparable to the "Mooi Indie" style. Besides using Western and Orientalist styles, he also uses themes from ancient Javanese tradition. The story of the Ramayana and the Mahabhara ta is also part of the oeuvre. However, in most paintings, Western influence can still be recognized, which is not surprising because he had studied in the Netherlands, Italy and France (Supangkat, Jim, 2005, p.206).

In this section several examples of artwork can be seen relating to the role of art under Sukarno's leadership. These examples explain various types of art under Sukarno. For each style, a clear example has been chosen to illustrate what the ideas of each group of artists involved were and what roles they played in the turbulent period from 1945 to 1967. Sukarno had contact with struggling nationalist artists, before the proclamation. This contact continued 
even after the proclamation of independence was announced in 1945. Sukarno tried to keep the artists and buy their works to complement his collection and artistic strength. For example, Hendra Gunawan is one of these artists. When Sukarno moved to Yogyakarta in 1946, Hendra Gunawan also joined him. He painted with realistic themes and performed in an expressionist style. In addition to the war scenes, Hendra Gunawan also paints a bad side of society. A good example of this is the painting on the Sidewalk of Yogyakarta. In 1947, Indonesia has been independent for two years, but according to Sukarno there is still no decolonization. Therefore, the oppressive atmosphere in the painting can refer to the oppressive situation during the colonization by the Dutch.

During his reign, Sukarno also appointed a Dullah as his personal painter. who is responsible for producing paintings, and organizes and places the President's collections in his various palaces (Knol, Meta, Remco Raben and Kitty Zijlmans, 2009, p.100). The two previous great painters, Affandi and Sudjojono, were the ones who pioneered Dullah, to make nationalist artists working for the Indonesian revolution and independence. Although he has such an important role model, his style seems different from his predecessors. Dullah's style can be called naturalistic, with a touch of Mooi Indie style. He painted among others many charming portraits of the Indonesian population, but not in a realistic or expressionistic way as did nationalist artists. This painting is called Miss Sasih, meaning "moon". The name also refers to the beauty of the woman depicted. In this painting the woman knelt down to pick up the flowers, precisely the flowers from the frangipani tree. These trees are planted to commemorate the deceased and flowers are often used in offerings and placed as memorials in the cemetery. The woman is fully dressed in traditional clothes.

\subsection{Tradition as a Critical Reflection on the Colonial Past}

From the 1930s until the period of the struggle for independence and the administration of President Soekarno afterwards, there was a lot of attention for social arts in Indonesia. This art is in conflict with many of the political authorities known to this country in recent history who prioritize the interests and identity of Indonesia. In 1965 General Suharto ended President Soekarno's regime. In this new order, which will last until 1998, there is almost no interest in the arts involved. Politics in Indonesia is no longer left oriented, but is developed from a model of economic policy adopted in capitalist countries. However, Indonesia's national identity and especially its search remain an important theme in politics. To strengthen this 'individuality', much attention is given to the country's various local cultures under the motto 'Bhinneka Tunggal Ika', where the Indonesian government encourages the development of traditional arts and crafts. Visual arts are interested in traditional crafts such as batik, and Puppet Theater.

Heri Dono is one of Indonesia's most famous contemporary artists. His art career began in the Yogyakarta art academy, but took a different turn when he was apprenticed to a puppeteer named Sigit Sukasman. This artist figure is known for successfully adapting to the modern ones he made in classic stories and which have been interpreted in puppet shows. Sigit Sukasman refers in his puppet play to contemporary problems and adapts his puppets accordingly. In the late 1980s, Heri Dono developed his own visual language in which the similarity to Sigit Sukasman's style and the influence of comics and television images could become recognizable. He combines the formal characteristics of Western cartoons such as Superman and Flash Gordon with elements from daily life in Yogyakarta. This connection was first expressed in a puppet show Wayang Legenda (1988) in which Heri Dono portrays religious stories and local myths in a modern way. Through sixty unique characters, it reminds us of superheroes, tourists and drunks. 
Finally, Indonesian art historian Jim Supangkat believes that Heri Dono referred several times in his work to Javanese morality through the representation of the struggle between good and evil. Jim Supangkat argues that artists try to connect this sense of traditional norms with his work with Indonesian society today (Supangkat, Jim, 2003, pp. 3038). However, this position can be criticized, because Heri Dono's art can be interpreted in different ways, so there is a possibility that the division between good and bad as evil is not apparent to viewers. This is Heri Dono's way of applying Indonesian traditions through his art. According to Matthew Isaac Cohen, the work when associated with post-traditionalism, is describing a political movement in which local traditional arts and crafts are deliberately used to uncover socio-political problems that occur (Cohen, Matthew Isaac, 2016, pp. 188-206). An artist who likes Heri Dono who is involved in socially critical arts is Eko Nugroho. He is a 'generation 2000' artist who, after the Reformation period in Indonesia, advocated the emergence of new art without rigid categories and differences. His work does not fall into a certain category because the use of comic material and visual language is seen as a combination of traditional Indonesian culture and everyday modern environment. In contrast, Eko Nugroho is primarily involved with the symbolic meaning of Indonesian and English by using it in a political context. Eko Nugroho uses tradition in different ways to refer to certain socio-political problems in Indonesian society in the past and present. He argues that in his work, for example, artists commented on one of the most important elements of Indonesian culture, namely the Islamic faith. He does this by describing the external aspects of trust characteristics such as the veil in his work. This is a craft that has preserved Javanese cultural identity during the colonial era and the Suharto dictatorship. Furthermore, by writing and speaking, is playing a major symbolic role in Eko Nugroho's work. The artist works with speech and acronyms to give deeper meaning to his art work, which is clear to everyone, even though it is not explicit. Eko Nugroho refers to the culture of proverbs. In Indonesian, the term proverb is a way of speaking without directly expressing anything (Supriyadi, Slamet, 2020, pp.367-369) According to Spielmann, artists use cultural elements of this language, because it is to question the political situation in Indonesia. The work entitled Dog People (2007) shows how Eko Nugroho used these aspects of Indonesian tradition to refer to his work based on an awareness of his past colonial experience.

\subsection{Art Development between 1998 - 2013: Suraji, Jompet Kuswidananto and Agung Kurniawan}

The post-Soeharto era is the center of this, which is the period from 1998 to the present. First, political change is discussed briefly, the extent to which they determine the time frame. Then several works of art are underlined, showing what they have in shaping an artistic identity. For this purpose it appears that artists are internationally known and how Indonesia places itself on the world map in the arts. In 2002 Indonesia was under the leadership of President Megawati Sukarnoputri and various improvements in various aspects of Indonesian people's life began. In a busy life in the 21 st century, it is the center of attention for a Suraji painting entitled The Competition of Life. Suraji studied art at the Yogyakarta Indonesian Art Institute and since then he has participated in many exhibitions. His paintings show the chaos of life in Indonesia during the political unrest. Business people, street vendors, cars, mopeds, bed jackets, bicycles, and airplanes dart on the left canvas. In the opposite direction, tourists are seen hovering above the chaos and filming or photographing it all. In the upper left of the picture, the crowd is greeted by the figure of someone wearing a hat and megaphone in his hand. Fear creates chaos, causing residents, regardless of ethnicity or political preference, to walk in the same direction. The tourists, on the other hand, don't seem to realize the chatic conditions and move in the opposite direction. They came in crowds, not noticing the figures running below them. Tourists seem to only see the surface of Indonesia, while there is much more going on below the surface. This painting has political commitment and the artist's 
character reflects his view of the chaotic time in his visual offer. Identities expressed in this way are not positive and nationalistic, as happened in the Sukarno era. Here you will also see traditional elements in this work, such as wayang kulit puppets. All figures on the canvas have chin angles, which are mainly related to the characteristics of puppets. A figure with a megaphone can be seen as a puppeteer, the person behind the canvas, who controls chaos.

Jompet Kuswidananto is an Indonesian artist and theater maker. In 2008 created installation art with mixed media from five works of art for Yokohama Triennial in Japan with the theme "Java's Machine: Phantasmagoria". Every piece of art has the same title: "War of Java: Do You Remember?" In the first part, five official attire of warriors are hung, so they truly represent a functioning figure. This was a soldier who fought during the Javanese War against the Dutch colonial occupation from 1825 to 1830. Each soldier carried a cas sette which told how the population was ordered to prepare for war (Jurriëns, Edwin, 2009, p.279). The second part is the installation art consisting of a video installation depicting a colonial sugar factory that is still producing. Among the pictures, there is a dancer moving to the rhythm of the factory turntable. This dancer may be the imagination of the present, whereas the sugar factory is the imagination of the past. This seems to make the colonial past still resound to the present. The third part consisted of the installation of formal clothing, this time the clothes belonging to the Javanese army. Some figures carry drums and others carry firearms. Pictures of dancers are also included in this section. He moves to the rhythm of the drum, once again making a division between the past and the present. The fourth part consists of live performances, specifically made for the opening of the installation in Yogyakarta. The show consists of a man carrying a moving guitar and making a sound on the recording that he listens to through his headset. This recording is related to the colonial past, which took place entirely from various events during the Dutch East Indies government. The player responds to recordings and even reads poetry from time to time. The fifth part consists of three costume figures that stand knee-high on the water. Water actually does not exist but is simulated using video images.

There are also pictures where the pages of the book are turned. The book is entitled History of Java, written by Lieutenant Governor Raffles during the British rule in the Dutch East Indies. In this work, Jompet tries to show the unwritten history behind uniforms and attributes, so in this way it tries to reconcile the present with the past, between "us" and "others" as article writers, Motion and Distortion: Media in the art of Jompet and Tintin, Edwin Jurriës articulated neatly (Jurriëns, Edwin, 2009, p.279). However, the title of the work does not show the same thing because 'phantasmagoria' does not have reconciliation in its meaning. The artwork seems to be bitter looking at the colonial past, when the Dutch occupied Indonesia. The installation seems to bring the past to the present through sound and images, but there seems to be no reconciliation. In my opinion, that the dancers, it is a kind of personification of the present, responding to the heavy voice of the past. It seems as though the artist wants to show that the colonial past has not been forgotten and is still part of contemporary Indonesian culture. The title of a separate part of the installation artwork does not reduce the bitter taste of this artwork.

Agung Kurniawan is an activist artist. He believes that art has social responsibility and can raise social problems. The theme in his work is related to this topic. He mostly works on the themes of violence, politics and taboo, because this is the biggest problem area that occurs in Indonesia. His work has to do with memories and history and he always works with photographs from his family's magazines, newspapers or photo books. In 2008 he produced 'The Dutch Day Dreamin', which was bought in 2013 by the Van Abbe museum in Eindhoven, the Netherlands. This work is a series of interconnected images, made with blue 
pastel and charcoal. The pictures show the struggle between two headless figures. One wore an ancient suit and the other wore a matching sarong and outerwear. In people's opinion the figure in a suit must represent the Netherlands and the other figure must represent Indonesia based on Indonesian traditional dress. It is not clear how to read the artwork so that in this case the standard direction is used, that is from left to right. The first picture shows the two figures in separate poses. The Dutch figure sat on the floor while an Indonesian figure was held at his feet and hung upside down. This figure also seemed to satisfy other figures verbally. In the second picture, the two figures are on the floor with the penis tied. The Dutch figure seems to write on someone else's chest, but it is unclear. The third picture shows a kind of struggle in which the Dutch figure controlled the Indonesian figure and sexually satisfied it. The fourth picture consists of Dutch figures who are dominated by Indonesian figures. It also seems to be seen in the mirror.

\section{Conclusion}

It can be said that contemporary Indonesian artists in this writing refer to their country's colonial history through traditional arts and culture, memories and political inclinations in contemporary society. This becomes clear from the visual language and interpretation of the works of art discussed, but is mainly evident from the intentions of the artists, which shows the relevance of this past. By considering the past, these artists saved Indonesia's colonial history from oblivion. They also called the traumatic story a warning for the future. These artists reflect their personal memories and identities and try to connect their vision of history and society today with Indonesia's national past. In these works, the colonial past is connected in other ways with the social problems that currently arise in Indonesia. Ecology and social inequality seem to be recurring themes related to the colonial past in the work of these artists. References to Indonesia's colonial past serve as a warning to the future, to damage existing power structures and to clarify the links between environmental, political and social interests. These motifs have been explored from the standpoint of "environmental art".

In 1995, it was the year that Indonesia also began to place its own art on the map at the international level. An exhibition was held in Jakarta with the participation of NonAligned Countries. In this exhibition which makes it the largest art event ever held in Indonesia. With this exhibition, art centers are not placed in the West. The main question of this exhibition is how participating countries contribute to the development of international art, not the question of the extent to which the west influences non-westerners. The role of Indonesia in the development of international art has not been explored during Soekarno order because he mainly has a national focus, and therefore is a positive change caused by Suharto's international focus. The Suharto figure began with a rough and bloody start in relation to art. While under Sukarno, he dominated the nationalist-oriented artists, so that nothing else happened under Suharto. He made nationalist artists cruelly suppressed, leaving other artists free to do whatever they wanted. However, this situation did not last long, because under President Sukarno there was no conducive search for a nationalist swish style, and only positive signs were found during Suharto's presidency. Instead of looking for style by looking at the present, personal style that sells can be developed based on ancient Javanese traditions. There is a great demand for Indonesian culture by tourists, among others, and the possibility to contemplate the current independent years is possible.

This writing seeks to map contemporary art from Indonesia and explain its relationship with the history of the country. Critical discussions of contemporary art from this country have only been in existence for several years, and further studies can therefore focus 
on ways of this art representation at Dutch and Indonesian art exhibitions. Because in the historical framework (art), which contemporary Indonesian art is presented? Although the mixed context of the exhibition discussed in this thesis has been briefly mentioned, in-depth research is relevant because it contributes to this artistic image. In addition, it is important to paint a more comprehensive picture of the various methods of working (contemporary) artists from Indonesia, so that this art and the underlying message can also be approached from their own art history rather than Western interpretations of contemporary art, which is now often seen as functioning as reference frame. The motives of Indonesian artists from this study to refer to their country's past are in line with the broader relevance of this study. Because by studying contemporary art about the history of the Netherlands and Indonesia, the colonial past of the two countries may no longer be rejected, but there may be more understanding of different interpretations of this history.

\section{References}

Bogaerts, Els (2015). “Whither Indonesian culture?' Rethinking 'culture' in Indonesia in a time of decolonization”. Heirs to world culture: being Indonesian, 1950-1956.

Bujono, Bambang (2012). "Galeri, Pendukung, Penyebar, Juga Pasar” dalam Bambang Bujono dan Wicaksono Adi (eds.) Seni Rupa Indonesia dalam Kritik dan Esai. Jakarta: Dewan Kesenian Jakarta

Cohen, Matthew Isaac (2016). "Global Modernities and Post-Traditional Shadow Puppetry in Contemporary Southeast Asia." Third Text 30, 3-4: 188-206.

de Bruin, Surya D. (2017). Beeldende kunst in Indonesië na 1945 : Welke rol speelde de kunst in de ontwikkeling van de nationale identiteit in Indonesië na de dekolonisatie?. Unpublished Master scriptie Universiteit van Amsterdam

Garraghan, G. J. (1957). A Guide To Historical Method. New York: Fordham University Press

George, K. (2008). "Ethical Pleasure, Visual Dzikir, and Artistic Subjectivity in Contemporary Indonesia." Material Religion

Hill, Hal (ed.) (1994). Indonesia's New Order: The Dynamics of Socio-Economic Transformation. University of Hawaii Press

Holt, Claire (1967). Art in Indonesia, Continuities and Change, Part Three, Cornell University Press, Ithaca

Iswahyudi (2020), "The Implementation of the Cultuurstelsel in Java: Cases in Afdeeling Demak and Grobogan, Central Java versus in Afdeeling Pacitan, East Java 1830-1870". Britain International of Humanities and Social Sciences (BIoHS) Journal Vol. 2, No. 3, October 2020, 657-668

Jurriëns, Edwin (2009). "Motion and Distortion: The media in the art of Jompet and Tintin". Indonesia and the Malay World Vol. 37,2009-Issue 109

Knol, Meta, Remco Raben dan Kitty Zijlmans (2009). Beyond the Dutch: Indonesia, the Netherlands and the Visual Arts, from 1900 until now. Amsterdam : KIT Publishers

Poshyananda,A. (1992). Modern art in Thailand, Nineteenth and Twentieth Centuries, Oxford University Press, New York, 1992.

Purnomo , Setianingsih (2016). Seni Rupa Masa Kolonial : Mooi Indie Vs Persagi. ULTIMART Jurnal Komunikasi Visual 7(2) November :7-17/ DOI: $10.31937 /$ ultimart.v7i2.391

Rath, Amanda, (20030. Shadow Stories: Wayang in the Work of Heri Dono - Indonesia, Prince Klaus Fund Journal \#10a: The Survival and Innovation of Crafts

Schefold, R. (1998). “The Domestication of Culture, Nation Buildings and Ethnics Diversity in Indonesia", Bijdragen tot de Taal-, Land en Volkenkunde van Nederlandsch-Indie, no. 154, Leiden 
Spanjaard, Helena (2018). Cita-cita Seni Lukis Indonesia Modern 1900 -1995: Sebuab Kreasi Identitas Kultural Nasional. Translated by Iswahyudi , Yogyakarta: Penerbit Ombak

Spanjaard, Helena (1993). "Modern Indonesian Painting, the relation with the west, Indonesian Modern Art. Amsterdam

Spanjaard, Helena (1990)."Bandung, The Laboratory of the West", dalam Fischer, J.,(ed.), Modern Indonesian Art, Three Generations of Tradition and Change, 1945-1990. Berkeley

Spanjaard, Helena (2016). Artists and their inspiration: a guide through Indonesian art history (19302015). Volendam: LM Publishers

Sudarmadji (1981). Pelukis dan Pematung Indonesia, Jakarta: Aries Alima

Sudarmadji (1991). "Persagi", Stream of Indonesian art, Jakarta

Sudjojono, S. (1964). Seni Lukis, Kesenian dan Seniman, Jogjakarta: Yayasan Aksara Indonesia

Supangkat, Jim (1979). Gerakan Seni Rupa Baru. Jakarta: PT. Gramedia

Supangkat, Jim, Sanento Yuliman (1982). G. Sidharta ditengah Seni Rupa Indonesia, Jakarta, Gramedia

Supangkat, Jim (1997). Indonesian Modern Art and Beyond, Jakarta: Indonesia Fine Arts Foundation

Supangkat, Jim (2003). "Upside-down Mind: The Art of Heri Dono." Prince Claus Fund Journal $10 \mathrm{a}, 30-38$

Supriyadi, Slamet (2020), "Pragmatic Analysis on G.M. Sudarta's Caricatures in Kompas Newspaper". Budapest International Research and Critics Institute-Journal (BIRCI-Journal) Volume 3, No 1, February 2020:367-378

Veiga, Leonor (2018). The Third Avant-garde. Contemporary Art from Southeast Asia RecallingTradition. Leiden, Proefschrift kunstgeschiedenis Universiteit Leiden

Vos, Ken, Els van der Plas et al. (eds.) (1993). Indonesian Modern art Indonesian Painting Since 1945. Gate Foundation

Wright, A. (1994). Soul, Spirit and Mountain, Preoccupations of contemporary Indonesian painters, Oxford University Press, Kuala Lumpur 


\section{List of Figure}

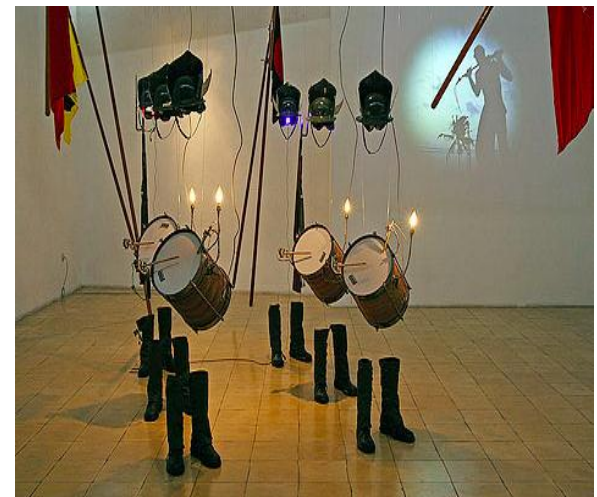

Figure 1. Jompet Kuswidananto, "War of Jawa, Do you remember?"

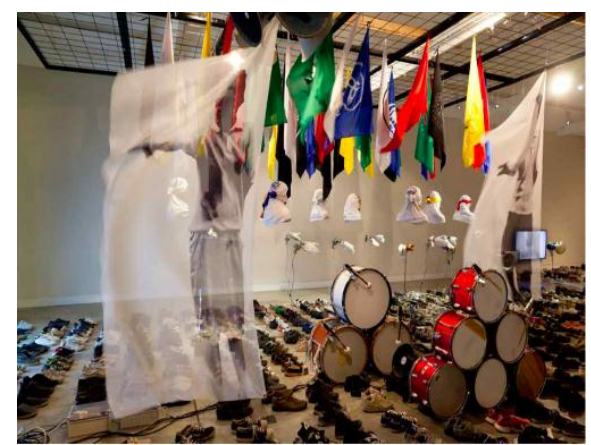

Figure 2. Jompet Kuswidananto, After Voices

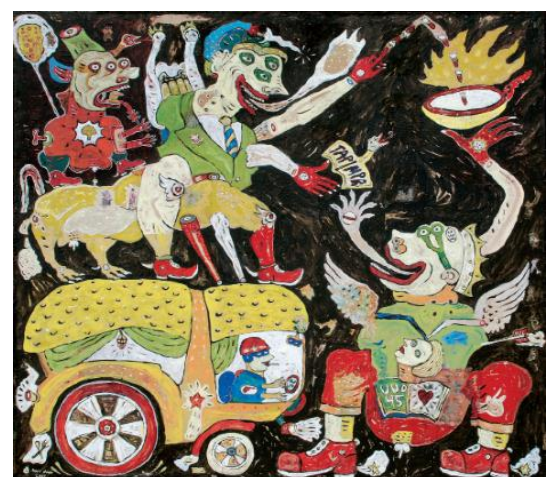

Figure 3. Heri Dono, "Political acrobat" 


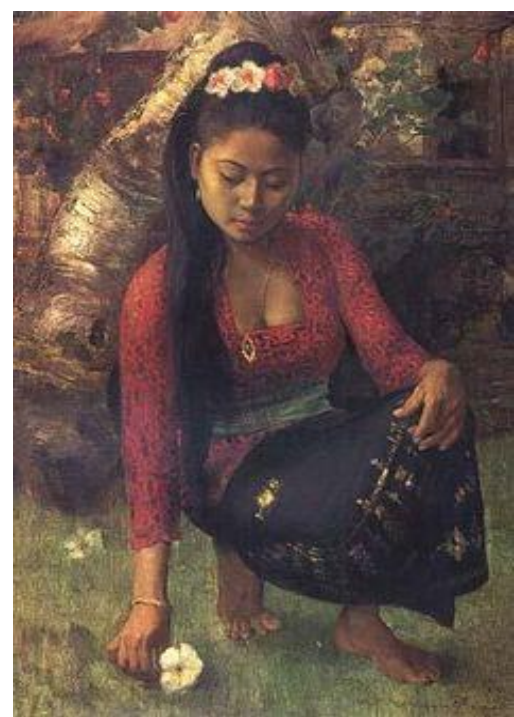

Figure 4. Dullah, "Miss Sasih, 1977"

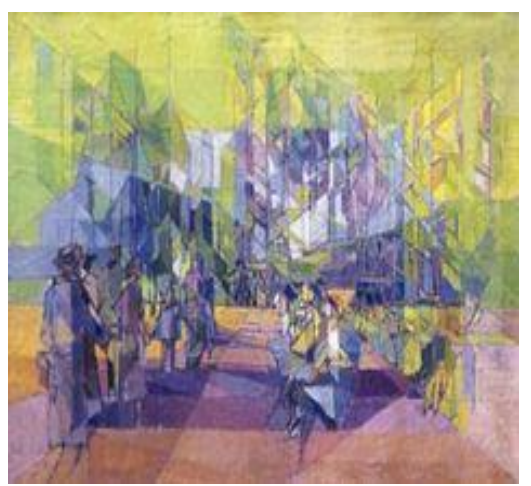

Figure 5. Ahmad Sadali, "Central parc of New York, 1957"

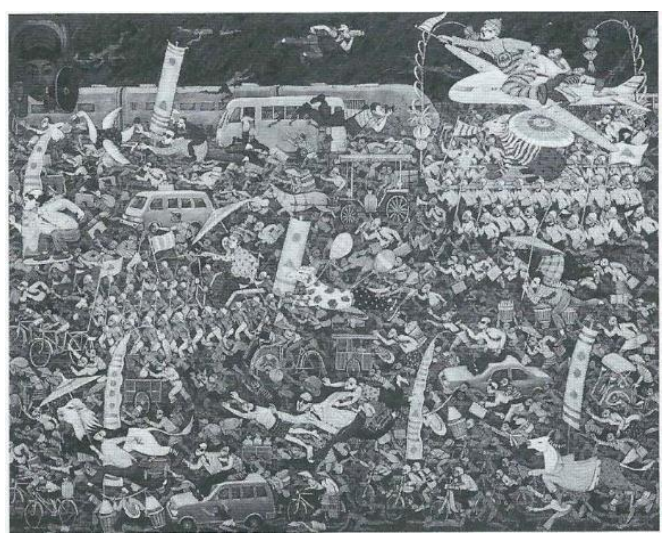

Figure 6. Suraji, "Competition of life" 


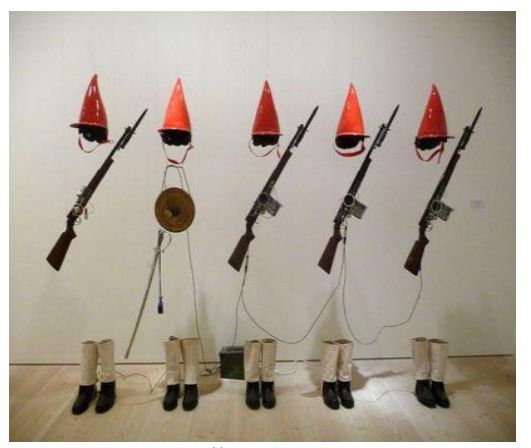

Figure 7. Jompet Kuswidananto, "War of Java: Do you remember?" 2008

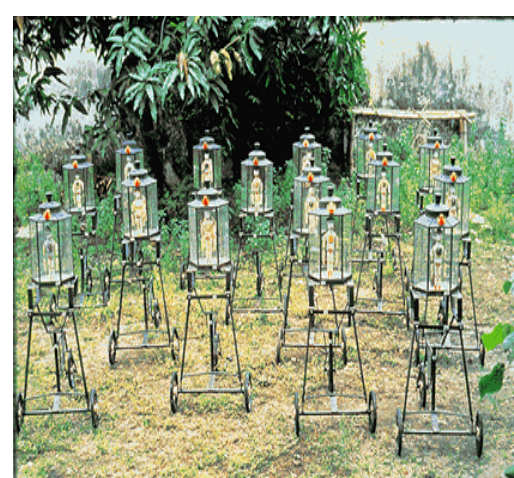

Figure 8. Heri Dono, "Glass vehicle", 1995,

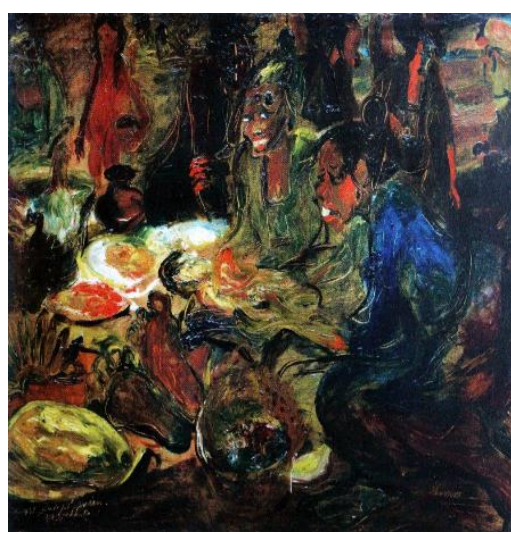

Figure 9. Hendra Gunawan, "On the Sidewalk of Yogyakarta", 1947

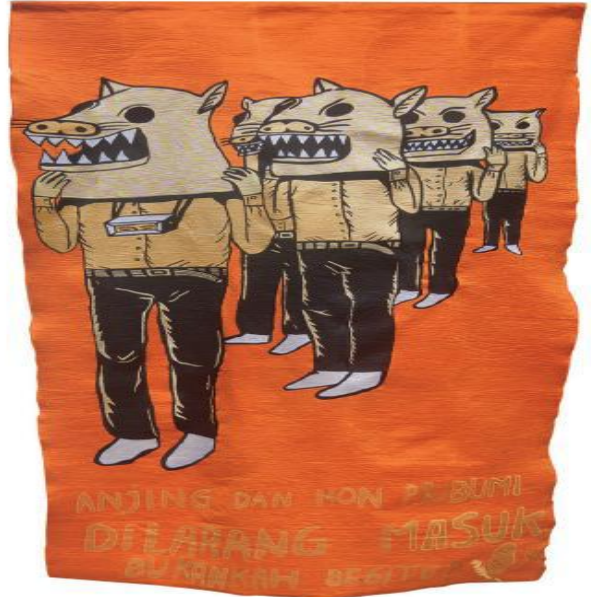

Figure 10. Eko Nugroho, “Dog People”, 2017 